\title{
ATYPICAL ACID-ALCOHOL-FAST BACILLI CULTURED FROM HUMAN URINES
}

\author{
BY \\ C. H. LACK, B. J. NEWMAN, F. A. TANNER, AND A. G. TOWERS \\ From the Department of Pathology, Institute of Orthopaedics and Royal National Orthopaedic Hospital, London
}

(RECEIVED FOR PUBLICATION AUGUST 4, 1956)

During the past seven years at this hospital the urines of all patients with skeletal tuberculosis have been examined at regular intervals with a view to detecting early renal infection. Our practice is to collect the first specimens passed on three successive mornings in sterile jars. These specimens are centrifuged in sterile tubes and samples of the deposits examined for pus and red cells and for acid-alcohol-fast bacilli. The deposits are stored at $-10^{\circ} \mathrm{C}$. until three have been examined, then they are pooled, the pool treated by Petroff's method and portions of the pool inoculated on to media and into a guinea-pig.

In the course of this work acid-alcohol bacilli have appeared on culture media which do not appear to be $M$. tuberculosis or any of the wellknown saprophytes. These mycobacteria (for we believe them to be so) were not studied in detail until they appeared in a sequence of urines from eight patients during January and February, 1954. This series all appeared to belong to the same species with the exception of two chromogens. In January and February, 1955, the urines of 21 patients, and in October and November, 1955, the urines of 16 patients, were found to contain a similar organism. The appearance and the disappearance of these mycobacteria could not be explained by any change in the method of collection, in procedure, or in personnel. Two patients whose urine contained them were out-patients and passed their urine into the sterile jars supplied by the laboratory without attending the wards.

A prolonged search has been made to track down the source of these mycobacteria without success. The Löwenstein media have been repeatedly examined for contamination at source. Cultures were made of washings of the glassware and of the reagents used from the time patients pass their urine to the time it is inoculated onto the Löwenstein media. The search has been fruitless. Pus, synovial fluid, and other liquid material sent from the wards for bacteriological examination has not been con- taminated to the same extent, though a similait organism was responsible for a false interpretations of a sensitivity test of $M$. tuberculosis.

\section{Incidence of Acid-alcohol-fast Mycobacteria}

The incidence has been of the order of $0.5 \%$ of pooled urine deposits, the majority being in thङ three series already mentioned. The average incubation period before growth appeared on Löwenstein' medium on primary isolation differed slightly in these three groups:

\begin{tabular}{|c|c|c|c|c|}
\hline Series & Period & $\begin{array}{l}\text { No. of } \\
\text { Cultures }\end{array}$ & $\begin{array}{c}\text { Average } \\
\text { Time }\end{array}$ & Range \\
\hline $\begin{array}{l}1 \\
2 \\
3\end{array}$ & $\begin{array}{l}\text { Jan. Feb., } 1954 \\
\text { Jan. Feb., } 1955 \\
\text { Oct. Nov., } 1955\end{array}$ & $\begin{array}{r}8 \\
21 \\
16\end{array}$ & $\begin{array}{l}2 \text { weeks } \\
3 \text {, } \\
1 \text { week }\end{array}$ & $\begin{array}{l}1-8 \text { weeks } \\
1-10 \text { days }\end{array}$ \\
\hline
\end{tabular}

During this period eight strains of $M$. tuberculosi were isolated from urines, none of which was: resistant to isoniazid or streptomycin.

\section{Methods}

After growth had been obtained from the primar@ inoculum on Löwenstein's medium at $37^{\circ} \mathrm{C}$. the following tests were carried out:

(1) Subculture on Löwenstein's medium and oळ glycerol agar at $37^{\circ} \mathrm{C}$. to observe rate and type of. growth, and on Löwenstein's medium at $22^{\circ} \mathrm{C}$.

(2) Subculture on nutrient agar at $22^{\circ} \mathrm{C}$. and $37^{\circ} \mathrm{C}$ ?

(3) Subculture on Hirsch's charcoal agar medium $10 \%$ horse blood agar, $10 \%$ horse blood+Glover స్టు medium, Dubos Tween albumin medium and Loeffler's serum.

(4) Survival at $60^{\circ} \mathrm{C}$. when subcultures on glycerof agar slants were held at $60^{\circ} \mathrm{C}$. for four hours, the cooled and stored at $37^{\circ} \mathrm{C}$. for two weeks and examineक for growth.

(5) Microscopic examination of cultures and fermem tation of rhamnose and arabinose were tested by the method described by Gordon and Smith (1953).

(6) Catalase activity was measured by taking equ\& volumes of an aqueous solution of $20 \%$ Tween 80 and 
30 volumes $\mathrm{H}_{2} \mathrm{O}_{2}$, adding one loopful of culture and observing the rate and amount of gas liberated (Middlebrook, 1954).

(7) Neutral Red Test.-Five millilitres $50 \%$ methyl alcohol was put in a centrifuge tube plus two loopfuls of a Dubos or Löwenstein culture rubbed in and incubated for one hour at $37^{\circ} \mathrm{C}$. The supernatant is decanted and replaced by another $5 \mathrm{ml}$. methyl alcohol and incubated for one hour and decanted. Five millilitres alkaline buffer ( $1 \%$ sodium barbital in $5 \% \mathrm{NaCl}$ solution not over two weeks old) plus $0.2 \mathrm{ml}$. of $0.05 \%$ aqueous solution of neutral red is added and the tube incubated at $37^{\circ} \mathrm{C}$. and well shaken every 15 minutes. The colour is graded from - to ++++ according to the degree of red on the bacteria. The reading is made easier by adding $2 \mathrm{ml}$. petroleum ether, shaking for two minutes and putting in the refrigerator for a day or two, when the positives will develop a deeper red at the interface.

(8) Methylene Blue Reduction Test.-This was tested by the method described by Bloch (1950).

(9) Sensitivity to Antimicrobials.-Isoniazid and streptomycin were diluted in Glover's medium to which $10 \%$ horse blood and the test organisms were added. After two weeks the bottles were centrifuged and the deposit examined after staining by Ziehl Neelsen's method. Control cultures without antibiotics were always included. This method gave a sharp end-point of no growth. Sensitivity to other antibiotics was determined grossly by incorporating the drugs in $25 \mathrm{~mm}$. filter paper discs, which were laid on $10 \%$ horse blood agar, and streaking up to the discs. The results were read after 14 days. The plates were kept in tins to prevent desiccation.

(10) Survival of Organisms in Mice.-All strains were grown in Dubos Tween albumin medium for one week and brought to a concentration of $1 \mathrm{mg}$. $/ \mathrm{ml}$., and $0.5 \mathrm{ml}$. of this suspension was inoculated intraperitoneally into groups of five mice per culture. One mouse from each group was killed by ether at the end of three, four, five, six, and seven weeks respectively and the spleen removed and homogenized. In addition to $0.02 \mathrm{ml}$. of the undiluted homogenate, similar volumes of $1 / 10,1 / 100$, and $1 / 1000$ dilutions were inoculated on to the surface of glycerol-blood-agar. These were incubated and the colonies counted after two and four weeks.

(11) Guinea-pig Inoculation.-Guinea-pigs were inoculated into the thigh with $2 \mathrm{mg}$. wet weight of a 14-day culture. They were killed after six weeks and smears of glands and spleen examined for acid-fast bacilli. In the case of the chromogenic strain which produced manifest disease, six guinea-pigs were inoculated, the last three being with 1 loopful of a seven-day Löwenstein culture emulsified in $1 \mathrm{ml}$. of saline which was injected into the thigh. In these instances tissues were fixed and examined histologically, and other portions were homogenized and cultured.

\section{Results}

The results of the morphological and cultural studies are set out in Table I, and a characteristic growth pattern is illustrated in Fig. 1.

TABLE I

MORPHOLOGY AND CULTURAL CHARACTERISTICS

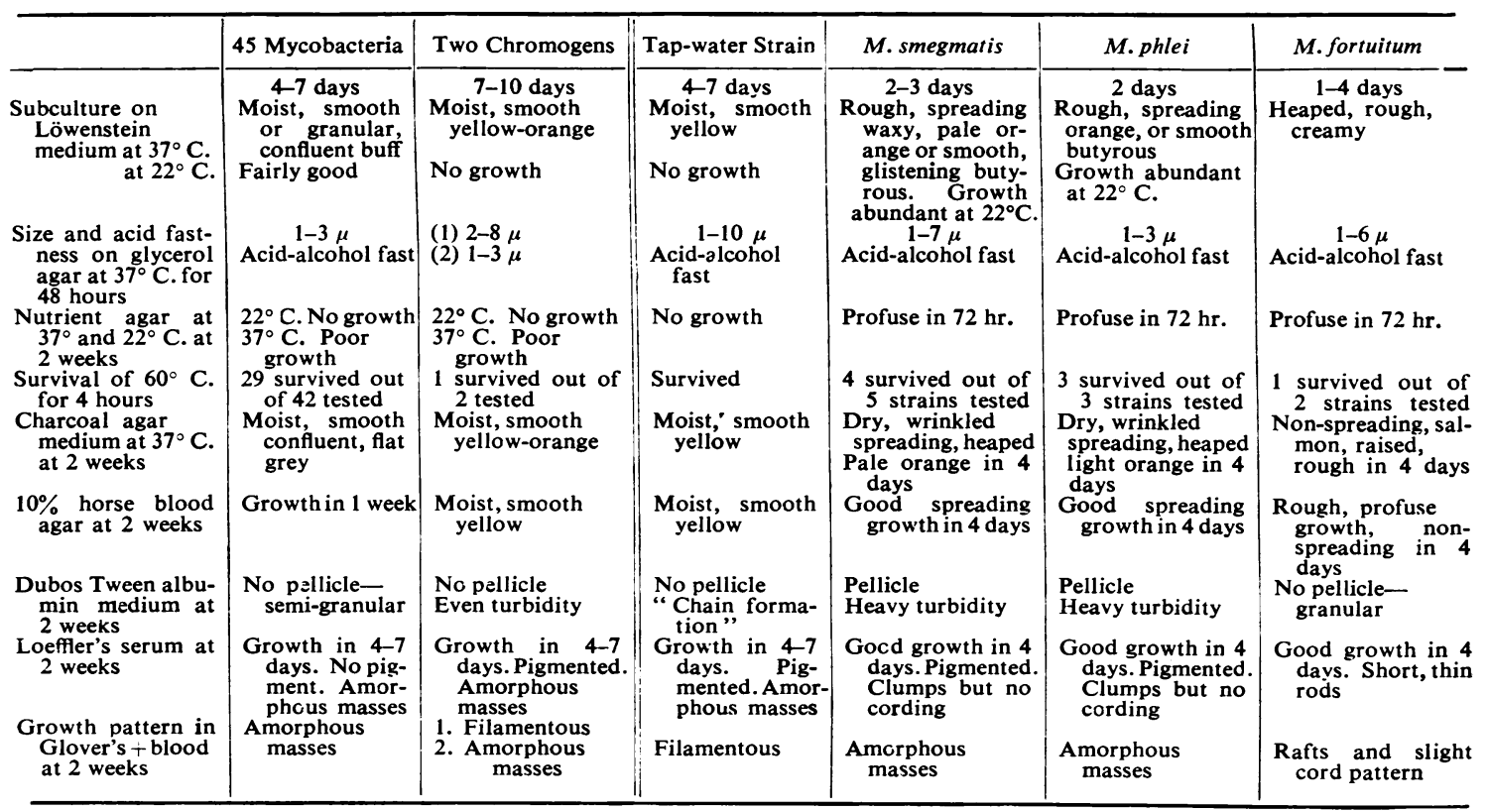


TABLE II

BIOCHEMICAL TESTS

\begin{tabular}{|c|c|c|c|c|c|c|c|}
\hline & & $\begin{array}{c}45 \\
\text { Mycobacteria }\end{array}$ & $\stackrel{2}{2}$ & $\begin{array}{l}\text { Tap-water } \\
\text { Strain }\end{array}$ & M. smegmatis & M.phlei & M. fortuitum \\
\hline $\begin{array}{c}\text { Fermentation of } \\
\text { and arabinose }\end{array}$ & rhamnose & $\begin{array}{l}\text { Rhamnose all - ve } \\
\text { Arabinose all - ve }\end{array}$ & $\begin{array}{l}\mathbf{R}- \\
\mathbf{A}-\end{array}$ & $\begin{array}{l}\mathbf{R}- \\
\mathbf{A}-\end{array}$ & $\begin{array}{l}\text { R all }- \\
\mathrm{A} \text { all }\end{array}$ & $\begin{array}{l}\mathbf{R} \text { all }- \\
\mathrm{A} \text { all }+\end{array}$ & $\begin{array}{l}\mathbf{R} \text { all - } \\
\mathbf{A} \text { all - }\end{array}$ \\
\hline Catalase $\quad \cdots$ & $\cdots \quad \cdots$ & Series $1 .+\square$ & 2. +++ & $+\div$ & $+\div$ & $++\div$ & $\div-$ \\
\hline Neutral red test & . $\quad \ldots$ & $19,43+$ & $1 .++$ & - & - & - & - \\
\hline $\begin{array}{l}\text { Methylene blue } \\
\text { test }\end{array}$ & reduction & $15-60 \mathrm{~min}$. & $\begin{array}{l}\text { 1. } 12 \mathrm{hr} \text {. } \\
\text { 2. } 13 \mathrm{~min} \text {. }\end{array}$ & $3 \mathrm{~min}$. & $3 \mathrm{~min}$. & $3 \mathrm{~min}$. & $14 \mathrm{~min}$. \\
\hline
\end{tabular}

TABLE III

DRUG SENSITIVITY TESTS

\begin{tabular}{|c|c|c|c|c|c|c|c|}
\hline & & $\begin{array}{c}45 \\
\text { Mycobacteria }\end{array}$ & 2 Chromogens & $\begin{array}{l}\text { Tap-water } \\
\text { Strain }\end{array}$ & M. smegmatis & M.phlei & M. fortuitum \\
\hline $\begin{array}{lll}\text { I.N.A.H. } & \ldots\end{array}$ & $\cdots$ & $\begin{array}{c}\text { Resistant to } \\
10 \mu \mathrm{g} . \mathrm{ml} .\end{array}$ & $\begin{array}{l}\text { Both resistant } \\
\text { to } 25 \mu \mathrm{g} . \mathrm{ml} \text {. }\end{array}$ & $\begin{array}{l}\text { Resistant to } \\
10 \mu \mathrm{g} . \mathrm{ml} \text {. }\end{array}$ & Sensitive & Sensitive & Sensitive \\
\hline Streptomycin $\quad$. & $\ldots$ & $\begin{array}{l}\text { Resistant to } \\
25 \mu \mathrm{g} . \mathrm{ml}\end{array}$ & $\begin{array}{l}\text { Both resistant } \\
\text { to } 25 \mu \mathrm{g} . \mathrm{ml} \text {. }\end{array}$ & $\begin{array}{l}\text { Resistant to } \\
25 \mu \mathrm{g} . \mathrm{ml} \text {. }\end{array}$ & , & , & , \\
\hline 50 units penicillin.. & $\cdots$ & Resistant & $\begin{array}{l}\text { 1. Sensitive } \\
\text { 2. Resistant }\end{array}$ & Sensitive & Resistant & $2 / 3$ resistant & ,. \\
\hline $5 \%$ sulphamerazine & $\cdots$ & , & 1. Sensitive & , & Sensitive & Sensitive & , \\
\hline $50 \mu \mathrm{g}$. chloromycetin & . & , & 1. & , & Resistant & Resistant &, \\
\hline $50 \mu \mathrm{g}$. aureomycin & $\cdots$ & , & 1. & , & , & , &, \\
\hline
\end{tabular}

The results of the biochemical and drug sensī tivity tests are set out in Tables II and III.

The results of the tests for bacterial survival

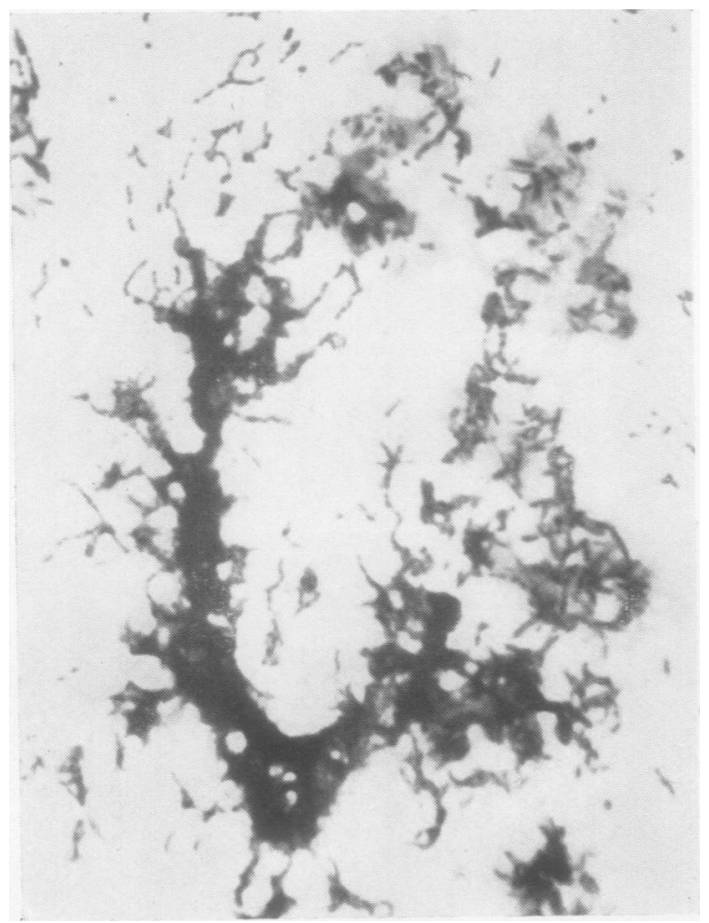

Fig. 1 mice for the "mycobacteria" strains are shown 7 Table IV. None were pathogenic for guinea-pigs.

TABLE IV

INFECTION OF MICE

\begin{tabular}{|c|c|c|c|c|c|}
\hline \multirow{3}{*}{$\begin{array}{c}\text { Myco- } \\
\text { bacteria }\end{array}$} & \multicolumn{5}{|c|}{50 or More Colonies from $0.02 \mathrm{ml}$. Spleen after } \\
\hline & 3 Weeks & 4 Weeks & 5 Weeks & 6 Weeks & 7 weeks \\
\hline & 2023 & $12 / 22$ & 720 & 515 & $2: 11$ \\
\hline $\begin{array}{l}\text { Chromo- } \\
\text { gen 1 } \\
\text { Chromo- } \\
\text { gen 2 }\end{array}$ & $\begin{array}{l}\text { Confluent } \\
\text { growth } \\
50 \\
\text { colonies }\end{array}$ & $\begin{array}{l}\text { No } \\
\text { growth } \\
\text { No } \\
\text { growth }\end{array}$ & $\begin{array}{l}\text { Confluent } \\
\text { growth } \\
\text { Confluent } \\
\text { growth }\end{array}$ & $\begin{array}{l}\text { Not } \\
\text { examined } \\
10 \\
\text { colonies }\end{array}$ & $\begin{array}{l}\text { Not } \\
\text { examing } \\
\text { No } \\
\text { growth }\end{array}$ \\
\hline
\end{tabular}

To sum up, an acid-alcohol-fast bacillus, 1-3 in length, in urines from 45 patients was found and has the following characteristics: In liquif media (Glover's blood) it grows in amorphouss masses; on glycerol-containing solid media forms a smooth, moist, buff-coloured colony arf grows well at room temperature and survive $60^{\circ} \mathrm{C}$. for four hours; it can survive for at least seven weeks in mice but is non-pathogenic fof guinea-pigs. Its lack of pigment and its inabilit to ferment rhamnose and arabinose and othef features distinguish it from $M$. smegmatis and $M$. phlei. Colonially it appears to be more like an avian bacillus or $M$. fortuitum, but its growtid 
at $22^{\circ} \mathrm{C}$. distinguishes it from the former and it is shorter and more uniform in size than the lacter. It is resistant to most antimicrobials and could be taken for a drug-resistant tubercle bacillus. It differs from isoniazid-resistant tubercle bacilli in that it combines catalase production with nonpathogenicity for guinea-pigs, but being able to grow at $22^{\circ} \mathrm{C}$. on glycerol-containing media is the important characteristic that distinguishes it from drug-resistant variants of $M$. tuberculosis.

Chromogenic Bacilli.-The first of these was isolated from the urine of a girl, Betty C., who had had a tuberculous hip since 1935. Saprophytic bacilli had been recovered from her urine in January and February, 1954, and one is included in the above strains. When a chromogenic bacillus was cultured from her urine in December, 1954, no particular attention was paid to it until the autumn of 1955. It had been freeze-dried in the interim, and when re-cultured was still highly chromogenic. A sample, $0.5 \mathrm{mg}$., was inoculated into two guineapigs and produced macroscopic disease in six weeks, and acid-fast bacilli were found in the spleen, liver, and regional lymph nodes, but in two other pigs no disease was manifest, but the spleen sections showed evidence of an inflammatory process, not very suggestive of tuberculosis, and with no demonstrable acid-fast bacilli. Further pathogenicity tests are in progress, and at present it can only be said that a chromogen has been isolated from the urine of a tuberculous patient and that this has many characteristics of a pathogenic strain.* It does not grow on Löwenstein medium at $22^{\circ} \mathrm{C}$., it takes 12 hours to reduce methylene blue, and give ++ in the neutral red test. Attempts to demonstrate a mixture of chromogen and a pathogen have no: been successful.

The other chromogen appears to be a true saprophyte, and warrants no further comment.

\section{Conclusions}

An acid-alcohol-fast bacillus has been recovered from the urines of 46 patients. It is non-pathogenic to guinea-pigs but is capable of surviving in mice for at least seven weeks. It does not appear to conform to any of the saprophytes.

A chromogenic acid-alcohol-fast bacillus has been recovered from the urine of one tuberculous patient. Its pathogenicity is in question.

\section{REFERENCES}

Bloch, H. (1950). Amer. Rev. Tuberc., 61, 270.

Gordon, Ruth E., and Smith, Mildred M. (1953). J. Bact., 66, 41

* These tests have now gone as far as we are prepared to take them. Eight more guinea-pigs have been inoculated with the culture of this strain, and no evidence of tuberculosis has been produced. This is a very unsatisfactory conclusion to offer, and there is no explanation. There is no evidence whatsoever that we were dealing explanation. There
with a mixture. 